\title{
ON THE NEW ECONOMIC PHILOSOPHY OF CRISIS MANAGEMENT IN THE EUROPEAN UNION
}

\author{
László Csaba \\ Member, Hungarian Academy of Sciences \\ Professor of International Political Economy, Central European University and Corvinus \\ University of Budapest \\ E-mail: csabal@ceu.hu
}

This essay attempts to go beyond presenting the bits and pieces of still ongoing crisis management in the EU. Instead it attempts at finding the 'red thread' behind a series of politically improvised decisions. Our fundamental research question asks whether basic economic lessons learned in the 1970s are still valid. Namely, that a crises emanating from either structural or regulatory weaknesses can and should not be remedied by demand management. Our second research question is the following: Can lacking internal commitment and conviction in any member state be replaced or substituted by external pressure or formalized procedures and sanctions? Under those angles we analyze the project on establishing a fiscal and banking union in the EU, as approved by the Council in December 2012.

JEL codes: F15, F36

Key words: banking union, fiscal federalism, European Monetary System, supranationalism, supervision of banks

\section{Introduction}

The management of the crisis in 2012 has brought perhaps more far reaching innovations in the actual workings of the European Union than anything since the adoption of the Maastricht Treaty in 1992. Most important changes, that bear - potentially or actually - systemic significance include (a) a fiscal union, meaning the obligatory coordination and real time control of national fiscal plans; (b) a banking union, implying a unified supervisory organ within the European Central Bank (ECB), with far-reaching competences to act even preemptively, and without prior consent of national authorities; (c) setting up the permanent bailout mechanism, the European Stability Mechanism, managing over 750 billion euros worth of assets; and last but not least (d) bond purchases of the ECB, including direct buying of obligations of indebted governments, and accepting those as full collateral for issuing new credit. The latter implies a quasi-fiscal activity and at the end of the day, monetizing debt, prohibited by the statutes of the ECB.

It is hard to see that the strict and far-reaching supervision of banks by the ECB, complementing the European Supervisory Agency, implies a resolute step away from inter-governmentalism and 
towards supranationalist arrangements. While British and Czech resistance has been open and vocal, other countries may join these in calling for referenda on each or some of the four items listed above. For the present inquiry we still presuppose that all the innovations will materialize sooner or later, in line with the original intentions. Thus we analyze what all this is to imply for the architecture and workings of the European Monetary Union (EMU), and how current nonmembers will be able to join in. ${ }^{1}$

We may set out from the premise, broadly documented in our previous writings on the subject, that one of the very few uncontested success stories of European integration has been the introduction of the single currency. It has complemented the single market, reflecting and also driving the 'ever closer union' in political, symbolic, economic and consumer terms. This success has built on the experience of unilateral pegging of the currencies of small corporatist states to the German mark, and later to the conversion of large continental EU members France, Spain and Italy - to 'monetary orthodoxy', allowing for sustaining their pegs to the Dmark for a decade and longer. In other cases, as Finland and Austria, the peg actually survived several decades, not just one, before merging in the euro.

This development has not been built on any specific economic theory, school, or ideology. This holds particularly to the frequently invoked 'neoliberalism' of the arrangement. As it is known, fixing - even more unilaterally pegging - the exchange rate has long been an anathema to the monetarists dominating the American universities (Friedman 1953). Political neoliberalism, triumphing on the ruins of the Soviet Empire, could not have been instrumental either. The project had been launched much earlier than the birth of neoliberalism, and basically by Christian Democrats and Socialists, both coming from the Franco-German statist tradition, and acting through the backdoor of sectoral policies and top-down arrangements like the European Steel and Coal Community and the Common Agricultural Policy. As in so many other instances in history, the result was not an outcome of specific and targeted constructivist projects, but one of social learning, via trials and errors, even if it involved a fair amount of diplomacy and a plethora of compromises (see Dyson - Featherstone 1999 for a more detailed discussion).

From the economic perspective it is axiomatic that if currencies are exchanged on the same rate for decades, the difference among them becomes nominal, notional, restricted to national symbolism rather than any financial substance. The only important difference of a currency union is the irrevocability of fixing. In broader terms it also means that the central monetary authority the ECB - being exempt - and institutionally insulated - from national political and fiscal pressures - may create money and credit, irrespective of the fiscal stance, and irrespective of the business cycle in individual regions.

In so doing the ECB imitates national central banks, which do not conduct monetary policies specifically directed to, say, California or Baden Würtenberg. Thereby the disciplined conduct of solid and sustainable public finance becomes a side-condition not only for price stability, but for

\footnotetext{
${ }^{1}$ Except for Denmark and the UK, all others - including the new member states - adopted contractual obligations to join EMU upon accession. Thus the question is when, rather than if.
} 
overall financial health. If this is more than a postulate, national current accounts become nominal, the same way the export-import balances of Reggio Emilia or Andalusia do not matter for the assessment of the public finances of Italy and Spain. ${ }^{2}$ Contrary to frequent claims, level of development differences in terms of per capita GDP do not necessarily translate into disintegration, as Russian, Chinese or US development in the past century indicates. Or if it does, it is a complementary variable, rather than the fundamental cause.

True, establishing monetary integration prior to - rather than following - political union has been singular to the EMU. But at the time of its evolution, which lasted for decades and built on trial and error, and successful currency pegging, nothing cautioned against this step. Most member-states - except for the notorious trespassers - introduced structural reforms, fiscal discipline, and managed to control the expansion of public debt. While these efforts were perhaps more resolute in the 90s, debt/GDP ratios stabilized between 2001 and 2008. From the ratio of $68.3 \%$ in 2001 , this indicator grew to $70.1 \%$ only by 2008 , despite the major massive bank bailouts performed already in the second half of 2008. By contrast, the failure of later crisis management is best summarized in the explosion of public debt since: by the middle of 2012 the ratio jumped to $89.1 \%{ }^{3}$ This limit is known to show the limit to where public debt becomes a danger for economic growth ${ }^{4}$.

With the benefit of hindsight one may well ask, how legitimate it was for us, economists, to treat political actors as rational agents following the maxims of economic theory, largely built on the rational expectations hypothesis. While in general terms it was just as much of a fallacy as taking homo oeconomicus at face value, especially pertaining to players of financial markets, who are known to follow herd behavior in most cases. On the other hand, it is hard to deny that a politician, fighting for re-election, is confronted with at least a minimum need of being able to deliver in economic terms in growingly materialistic European societies. This holds all the more so, when - unlike in the UK and USA - the election system does allow for the entry of new, protest movements in legislation, and even in governmental positions (see recent advances by Vlaams Blok and of the True Finns). In other words, politics ceased to be a closed shop and nonperformers are being voted out.

Therefore one may not even consider that some players - behaving strategically - deteriorated economic performance on purpose. On the other hand, it is a novelty of the first decade of the new millennium that at least in some countries, successive governments did shy away from any major restructuring. While this is in line with the ruling paradigm of rational choice in political science, it is very unlike the experience of the entire 1945-2000 period, when major transformations have taken place both in the East and West of Europe. In terms of the EMU, it is hard to forget that the monetary union was in fact a toll collected from Germany in exchange for

\footnotetext{
${ }^{2}$ True, mismanagement of regions may and does contribute to the current macro-economic disequilibria in both nations. But this is distinct from claiming a need for separate monetary policies for each - the latter, as in Catalunia, translates into eventual secession, which is not part of the original EMU ballgame.

${ }^{3}$ Source of data, unless otherwise indicated, is the ECB's Statistics Pocket Book (October, 2012, Frankfurt).

${ }^{4}$ The seminal book by Reinhart and Rogoff (2011) and a series of their subsequent writings amply demonstrate this empirical observation for the past 200 years in all market economies.
} 
agreeing to the project of political union (in Germany and EU alike). Also the track record of the nineties made pledges, commitments to improving fiscal sustainability through welfare reforms sounded credible, plausible and doable in the medium to long run, not least owing to the incentives of an open political system based on exit and entry of new parties/political forces, as this has already occurred in the 1980s and led to governmental participation in case of some former outcasts, as the Greens in France and Germany during the 1990s. This is very unlike the Anglo-Saxon tradition of bipartisan rule on which most political science models of rational choice are based, thus we cannot claim that incentives for change were non-existent from the very outset.

\section{A Flawed Architecture or a Flawed Implementation?}

In a considerable part of the literature (e.g. Daianu 2012; Mayer 2012) the opinion is voiced that the EMU failed because it has been built on sand. On the other hand, not only our introduction above contrasts with this view. The fact that fixed exchange rates could co-exist for several decades is itself an indication that the foundations are solid, workable, unless major trespassing occurs. In other words, there is no need for the complex surveillance and enforcement mechanisms, which have developed in the Treaties of Maastricht, Amsterdam, Nice and Lisbon, to ensure fiscal compliance. As the detailed description of the system shows (de Haan et al. 2010), if fiscal prudence - as a form of selfish behavior - prevails, compliance is ensured even in the lack of surveillance and sanctions. And conversely: if there is no commitment, if there is no conviction of the inherent uses and value of behaving well, trespassing will be the rule. The more rigid rules emerge to punish non-compliance, the bigger deviations - and the stronger the incentive to non-abide - will be. If a country does not want to relapse in the inflationary policies of the 1970s, it will avoid, on its own and without any external disciplining, the explosion of debts, public and private, in order to forestall the inflationary outcome, which is in the medium run inevitable in all economic theories.

Furthermore it also follows - especially in the resurfacing Keynesian framework of thinking that governments may spend themselves out of recession only under two severe conditions:

1. There are a number of underutilized and competitive capacities, which are quick to be used once effective demand allows for that. In other words, recession is cyclical, rather than structural. It is hard to believe, that say, the car industry in Germany or the real estate market in Spain was under such conditions in 2008-09.

2. There is sufficient elbow room, created by debt reduction strategies - results rather than proclamations - in the preceding period.

As we have seen above, in 2001-2008 next to no improvement happened at the euro-zone level, despite improvement in some small economies. The founding fathers of the euro therefore wondered if all the necessary structural reforms will indeed be realized in the weaker countries, in order to pre-empt fiscal derailment (Issing et al. 2004). And they were quite right, and were 
saying so before. However the non-reform scenario - which did happen in the South - was not replicated in the North, not even in the poor Baltic states.

What wisdom can be added to what is summed up above by the study of ongoing crisis management in the euro-zone? Without re-stating earlier accounts (Palánkai 2012; Csaba 2012) we may advance, that some countries fared pretty well. These were the ones which did follow not only preached - rules-based fiscal policies, which did attain price stability - not only in statistical terms of headline inflation but also in terms of underlying factors - and ones which did care about the stability and solidity of the banking sector, even if the latter falls outside the scope of public finance, regulated by the Stability and Growth Pact (SGP) and other EU level fiscal arrangements.

In short, these countries - including Slovakia, Estonia, Luxemburg, Austria and the Netherlands - avoided the minimalist approach that reigned in the problem countries. By the same token it did not require additional efforts - over and above the ones taken on their own initiatives - to deliver and meet all conditions laid down in the Treaties. Let us be explicit: those who survived the crisis in good shape were not the ones who adhered to the EU's rules of the game. They tended to outperform, on their own, the commandments of stability and sound conduct of public finance and banking supervision. It is known that for instance Belgium and Germany regularly missed the debt criterion of the SGP, without heading for trouble. By contrast, Ireland, Estonia and Spain, while being excellent pupils in terms of fiscal stringency, all suffered from the tremors of 2008-2012 period.

We may observe, already at this early stage, that the escalation of the previously hidden crisis of public debt in the EU is by no means directly related to the concept or the architecture of EMU. It also does not allow for those wide ranging generalizations, which emanate mostly from the British daily press - traditionally hostile to the EMU - that the whole project is 'unworkable' or 'hostile to realities' or followed a 'flawed design'. As we have seen, countries at various levels of development, various cultural backgrounds and various political orientations managed to live quite well with this 'crazy arrangement'.

Therefore we cannot subscribe to the view, expressed by respectable authors (Laski Podkaminer 2012) which declare the very criteria, rather than their application, to be infeasible and unpractical. We also do not see any proof for the classical claim by Feldstein (1997) that regions with uneven levels of development and dissimilar economic structures were unfit for a currency union. The latter statement is simply ahistoric, as the examples of the Austro-Hungarian Monarchy or the Ottoman Empire demonstrate. None have seen any convergence in terms of regional per capita GDP, and none of them collapsed for this reason. On the contrary, both of them flourished for several decades, until a lost First World War led to their partition, the same way the Holy Roman Empire was dismembered in 1806 by Napoleonic conquest.

In fact, economic history cautions us from buying in the claims of neoclassical models in terms of convergence, as it tended to be the exception rather than the rule (see the case of China, Russia, or the USA). In historical statistics what is observable is not convergence in the long run, 
but an ongoing change of relative positions of countries, with some - but very few - big advances, others - also a few - lagging behind, and a large number remaining in an unchanged relative position (see more recently Acemoglu and Robinson 2012). This book also invokes the long forgotten insight about the relevance of historic conditions, quality of institutions and social value sets in explaining the outcomes, against factor endowments and other mechanistic variables. If we do not expect convergence, a rare event in history, to repeat itself, than nonconvergence per se has no message for the EU, its crisis management, or even the global economy's prospects.

In our case it is easy to see that invoking level of differences in development is though intuitively strong, it is still a fallacy. Estonia, which is about Hungary's level of development in terms of per capita income, managed to overcome the crisis at the cost of one single year's recession, and growth resumed in 2010-12. The country joined EMU in 2011. By contrast, much wealthier old EMU states, like Italy, Spain and Ireland, have still been suffering from repercussions of the crisis at the time of writing. In sum, the reference to level of development as a major explanatory factor simply does not hold, no matter how widely held a claim it is. Factors other than the 'flawed EMU architecture', i.e. the much cited 'one-size-fits-all' proposition need to be revised.

\section{Common Currency and Structural Reforms: Which Way Does Causality Run?}

There are two complementary insights emanating from the growing industry of crisis explanations, produced by international agencies and think tanks alike. On the one hand these support the original propositions formulated at the time of launching the EMU project. These suggested that joining in a currency union has overwhelming benefits for the overwhelming part of players, however it also entails risks. Should countries not be able or willing to pursue price stability as an organic outcome of macroeconomic interplay, and thus should they be unable to sustain what used to be the unilateral peg of their national money, they might run into trouble. All the more so, if they do not make up for the loss of monetary and exchange rate policy instruments for targeted fiscal policy intervention, structural policy and liberalization of labor markets, as well as rendering welfare arrangements sustainable financially, derailment is no longer an if, but a when. The SGP, the Broad Economic Policy Guidelines, the convergence and stability programs, as well as the more recent innovations as the Fiscal Compact and the newly launched project of a fiscal union all point in this very direction.

The basic counter-argument may go as follows (see e.g. Muraközy 2012). The size and modalities of the welfare state, and expectations for the state to provide welfare services as citizens' rights, have long been built into the preferences of most of the electorate. Thus welfare states represent revealed preferences of the majority, and so any attempt to cut them radically is likely to founder. However, as the same article documents at great length, structural changes in expenditure patterns and incremental changes towards more fiscal sustainability of welfare provision have already made ways in the years preceding the financial turmoil, in old and new member-states alike. It is equally important that labor markets have started to become more 
flexible and provisions of social benefit became targeted, often means-tested, with the German Harz IV and the Dutch Polder model being perhaps the best known, together with flexicurity, the Danish concept elevated to the level of EU polices (van Rie and Mary 2012).

As a second, distinct group we may list those countries, where teachings of basic marcoeconomic textbooks were taken perhaps too much at face value. At the level of financial theory, the efficient markets hypotheses (Fama 1970), at the level of policy practice, the conduct of low interest rate policy at good times and bad, and the avoidance of any burst of any bubbles, as practiced consciously by Alan Greenspan (2008), shaped much of the outcomes. However, opportunism - or simply following intellectual and political fashions - does not follow from the original monetary model of integration. On the contrary, at the abstract level both fiscal and monetary policies should have been focused on medium to long term events, as aging or implications of the debt overhang, or ramifications of exploding private debt, be that in construction or banking. Thus we are less than surprised to note that the staunchest critics of the EMU emerged from the libertarian camp, as Milton Friedman, Václáv Klaus or Martin Feldstein, all calling any rules-based policy - and especially the irrevocability of exchange rate peg - as the triumph of politics over economics.

While analyses on the derailment of Greece and Italy abound, to which we may add only new data or anecdotal evidence, there is much less attention devoted to the second group. This includes in our reading Spain, Ireland, Romania and Estonia. The common feature of those economies is that stringency and regulation applied to the public sector only, therefore their fiscal accounts looked okay at the time of the eruption of the crisis. By contrast, the private sector - which accounts for a considerably larger part of GDP in all European economies remained largely unregulated. This was particularly noticeable in the financial and banking sectors - the latter two overlapping to a considerable degree. The staff of the Irish financial regulatory agency added up to three professionals, symbolizing the largely ideological fear of the Irish government from any regulatory intervention in financial markets (more on that in Connor and O'Kelly 2012). This was perhaps a case of taking the non-interventionist stance of contemporary mainstream economics too much at face value, even when deciding over practical matters.

But it would be wrong to invoke, as usually, the 'too big to fail' argument. In the case of Spain the regulation was truly meticulous, covering the Ministry of Finance, the Central Bank, the supervisory authority, regional governments, savings' banks and also large transnationalized banks, following international accounting standards closely. With reference to these arrangement the Zapatero government repeatedly announced during 2009-2010 that finances of both the autonomous regions and of the savings' banks, financing much of the population, have been solidified and sound. This claim was barely credible, given the structure of the Spanish boom of the 2000-2008 period. The latter was based largely on tourism and the construction industry, with banks lavishly financing both, in line with the Zeitgeist. This was only exacerbated by interbank operations, largely unrelated to financing the real economy, which rendered the formally strict national regulation hollow. Local savings' banks were though tightly under 
governmental control. However their supervision was often void of elementary professional skills, let alone personal integrity, as these were intimately intertwined with the ruling class (Garciano 2012). Thus the tremors triggered by the spillover of the global financial crisis should not have been surprising at all.

The situation was in many ways comparable also in Romania and Estonia. In both countries one could observe a large degree of overheating in 1999-2008, including the non-application of available brakes for cooling the economy, combined with very liberal application of regulations, if at all. As a consequence, prudent fiscal policies proved insufficient to forestall macroeconomic derailment, compromising the performance of the entire decade. According to the statistics of the ECB, Romanian public debt in 2008 stood at the low of only 13.4\%, on par with the traditional champ, Luxembourg. In Estonia virtue was even more pronounced, with public debt running at $4.5 \%$ of GDP in 2008 , which must be the world record of the year. Thus the situation of the two new member states is comparable more to Ireland than to Spain or Italy. This parallel implies that troubles accumulated in the private, rather than in the public sector, with economic policy/ideology leading to a hands-off stance - something we may term a new brand of macroeconomic populism.

Without getting into the nitty-gritty of individual stories we may well ask at this point: if the pattern of crisis is similar in the countries, is it not an immediate proof of the failed construction of EMU? Is it not that the limited focus - on public sector finances only - is at the root of subsequent troubles, that resurfaced in the private sector?

This suggestion does carry a modicum of truth. However it seems to neglect salient features of the EU. In short, especially following the ratification of the Lisbon Treaty in all the 27 member states, the EU has become even more intergovernmentalist than before. Final decisions rest ultimately with the respective national legislations, not with any of the common organs (with the proverbial exceptions of the ECB and in some cases the European Court of Justice, passing directly applicable rulings). In order to preempt fiscal trespassing, one option is to adopt national fiscal rules, mirroring the SGP (Benczes 2011), as later stipulated by the Fiscal Compact of March 2012. Or alternatively, we acknowledge, that national and EU level legislations co-exist, and any joint legislation must be anchored in inter-governmental agreements, open and explicit transfer of sovereignty, which remains the exception rather than the rule (more on that in Vörös 2012). ${ }^{5}$ The comparison of the Spanish to the Irish cases warns of the threats inherent in both under- and over-regulation, especially in the financial sector, as well as of the landmines of a too cozy relationship between the financial sector and its regulators, which may lead to conflict of interest situations more often than postulated in integration theory.

This of course means that setting up a joint supranational supervisory agency over all major European banks in the framework of the ECB, is going to be a formidable task, with a series of regulatory competences, procedures and other practicalities to be settled. The fine print is likely

\footnotetext{
${ }^{5}$ It is unsurprising to observe that the Council of December 2012 delayed the decision on fiscal union to the indefinite future, without setting a deadline - not a good news for any bureaucracy.
} 
to matter more than the general declarations of intent. ${ }^{6}$ The compromise of December 2012 consists in the following: (a) only about 100 'systemically important' banks will be under direct ECB supervision; (b) thus most of the rest of the 6,000 units in question remain under national supervision; (c) as a rule, bail-outs must be funded from national coffers; and (d) there is a cap on the use of ESM funds and serious pre-conditions for their use. ${ }^{7}$ True, the 'unlimited liquidity provision' of the ECB may render all the brakes illusory, at least in the medium run.

Let us underscore: supervising banks, with cross-border authority, and the right of preemptive action is anything but a technical matter, as suggested by the working documents of the Commission in their various editions in between June and December 2012. The arrangement, to be elaborated and implemented by January 2014 is about competences, about ways of overcoming collusions across national legislations, about ways of managing drifts between EU and national arrangements, and not least about hundreds of billion euros in assets and the way these are managed. If all these were to be vested with the second leg of the ECB, and empowered with the exceptional jurisdiction of the ECJ, allowing for immediate validity without proper instances to appeal against them, these steps would transfer an exceptional degree of sovereignty to un-elected supranational organs.

Let us note: already the bailout fund, the ESM, of 750 billion euros, and the fact that since the December 2012 Council the ECB may directly intervene in troubled banks, with its money transfer not showing up in the accounts on national public debt, the transfer of sovereignty, way above the current 132 billion euros or 1\%of GNI, has already materialized. Further sovereignty transfers would require elaboration of the fine print, as formulated above, and perhaps, in several countries, a referendum or decisions of the Constitutional Courts on the legality of the arrangement and on the proper ways of inserting these steps in national legislation. Not only the UK, but the Czech Republic, the German Constitutional Court and a number of smaller countries, including Slovakia have already voiced their concerns. The fear of smaller states to be run over is palpable and legitimate. Poland and Sweden have already voiced the view that non euro-zone members should have voting rights in all matters pertaining to banking.

This concern is rooted in the fact that banking is already de facto transnationalized, thus any measure pertaining to euro zone members are of direct concern to the rest. For instance in January, 2009 when Ireland unilaterally declared a general deposit insurance by the state, irrespective of the size of the holdings, this had to be generalized in hours rather than days, irrespective of the weighty moral hazard considerations that could have cautioned against such a step. By contrast, the one country-one vote principle may create situations where Cyprus or

\footnotetext{
${ }^{6}$ At the time of concluding this paper the European Council adopted only guidelines for, rather than a detailed regulation of, EU wide banking supervision, as envisaged in the letter of President van Rompuy of June 2012. Furthermore the competences, procedures and fora for arbitration are yet to be elaborated, thus the agreement, if it ever is reached, is unlikely to come soon. It is no secret that the UK, a financial centre of the globe, flatly rejects any supranational regulation of its banking sector (and by implication, of other countries' financial industries), thus yet another opt-out from joint supervision in ensured.

${ }^{7}$ See the resolution of the Council and positions, as reported in Euractiv,13-14 December, 2012, as well as 'Europe wins a battle, not yet the war' in the Wall Street Journal, 15 December 2012.
} 
Latvia could veto a complex deal hammered out by others via a series of tough compromises, for reasons that may or may not relate to the substance of the deal. In the opposite case the 'one money, one market' principle, with supranational regulation, may simply preempt basic features of national sovereignty in fiscal matters, but also - in banking - for the private sector.

\section{On the Changing Role of the ECB}

Financial market analysts and policy-makers tend to be positive about the change brought about by the new, Italian President of the ECB. His predecessor, Jean Claude Trichet was mocked by his critics to be 'more German as the Germans' because of his commitment to the independence of the ECB and the single-minded focus on preserving price stability - while avoiding deflation - which he in fact succeeded in. Defying the spirit of the ECB being an 'augmented Buba' as well as the letters of its statutes, the ECB has gradually relapsed into a series of quasi-fiscal activities. Emulating the practices of the FED rather than the Bundesbank, the ECB first purchased debt obligations of troubled euro zone members on the secondary market.

It also instituted a series of liquidity enhancing measures. Since September 2012 it has been actively involved in buying government bonds on the primary market and providing 'unlimited amounts of liquidity' to save toe single currency. The December 2012 Council approved the practice of buying the assets of troubled banks directly, thus 'saving' on the published gross deficit numbers of the home country. While the latter is good news for money markets, bad news for anyone concerned about basic principles of proper and sound accounting, at micro and macro levels alike. As one observer put it aptly, the ECB has never been so powerful in terms of market standing, and never been so weak in terms of independence from daily political considerations in theoretical terms its independence has become a fiction (Schnaas 2012).

On the more abstract level of economic theory, it has never been seriously questioned since the late 1970s that the Keynesian type of demand management is meant to remedy cyclical ills only. By contrast structural and regulatory weaknesses and the troubles emanating from these can, neither in theory nor in practice, be cured by easy money. Not only has the experience of Western Europe, but also of Japan in the 1990s vouched warranty for the validity of this insight. And we argued in the previous section, that over- and under-regulation, as well as structural flaws and policy blunders, not external shocks were behind the recession of 2009 in the EU. This situation is only exacerbated by the fact that public debt continues to grow, basically in all three major poles of the global economy - that is not just in the EU, but in the USA and Japan alike. While EU debt is to peak with $90 \%$ of GDP, the USA figure is around $105 \%$ and that of Japan $240 \%$.

True, we do have excellent students in the class of the EU, such as Luxembourg, Estonia and Slovakia, but these regrettably do not include any of the four major economies. Moreover public debt continued to increase in 2010-2012, when the global financial crisis was already over. While IMF data show an increase of global output in the range of 3 to $5 \%$ per annum, there is no sign of declining debt rates predicted by theory in any of the three major locomotives of the 
global economy. Governments have long forgotten the maxim of Lord Keynes on the symmetry of fiscal policy, let alone the even stinger maxims of the Austrian school or of monetarists.

This is quite a problem insofar as we accept the compelling arguments why global imbalances tend to be managed by the surplus of one region counterbalanced by the deficit of the other (Feldstein 2008). As the above cited article proves convincingly, aiming at a global 'general equilibrium' in any point of time would automatically trigger a world-wide recession, with both surplus and deficit countries suffering in an unnecessary manner.

What is indeed a major source of trouble that in most of the global economy it is not only the government, but also the two other principal agents of the economy run structural deficits, i.e. households and corporations alike. In short, the textbook identity on the overall balancing act across the three major holders of income does not hold. This is a problem as long as we have relatively few countries like Saudi Arabia, running a structural surplus in savings, against many countries like the USA, where deficits of all three major players are structural.

It is hard to question that if there are not sufficient voluntary savings at the global level, financial intermediation has nothing to channel. If this phenomenon is structural, emission of credit and money may help only in the short run, and the ramifications already in the medium run are devastating.

For the time being we are entering in a paradoxical situation. While IMF statistics show an annual growth rate between 3 and $5 \%$, which is quite considerable in historical standards, both fiscal and monetary policies continue to be lax and expansionary in all the three major centers of global economy. One may comment that this at least avoids the unhealthy mix of the early 1980s, which lead the US to a recession at the time. But this is a cheap argument. If both legs of economic policies continue to be expansive at times of growth, the revival of inflation is just a matter of time, not a matter of 'if'. Furthermore if the economic lull is due to over-extension of household and corporate debt, of weak innovation, or other structural factors, including the noncalculability of overall economic conditions, weak supply may co-exist and supplant extensive availability of money and credit. And this is precisely the established recipe for stagflation, known from the 1970s. This danger is so imminent, that - following the classical Lucas Critique (1976) all holders of money and income are well advised to refrain from spending - which turns into the drying up of money markets.

Thus it is hardly surprising that in his Nobel lecture the renowned financial economist Thomas Sargent (2012) drew a parallel with the current state of the EU with the pre-civil war, confederative USA. The parallel is established on the grounds of the US confederative budget accounting for about $1 \%$ of GDP, i.e. comparable to that of the current EU. The basic difference is that the US was by no means a welfare state, unlike most of EU states today. His conclusion is that an efficient solution to the debt problem is by and large the opposite of what we observe in the EU today. Instead of providing unlimited liquidity, the solution is the ensuring of the no bailout clause - the single, non-replicable experience of a bailout, just the opposite to what we 
observe in Greece and other indebted nations. By contrast the US has never bailed out any member state, irrespective of its political ramifications.

It is less than trivial, if the German-inspired practice of trying to offset the dire consequences of the policy of easy money can be countervailed by unification and more rigid application of EU level rules and regulations. The underlying factor is not just the different debt dynamics of the EU member states, but also their divergent social and welfare models. For this reason both the pattern and dynamics of public spending is unlikely to be liable to joint, unified handling, let alone their union.

The latter observation holds also for the US. As it is known, individual states have different social and fiscal practices, with federal level welfare initiatives surfacing only during the Obama administration (perhaps not at the best conceivable point of time). As long as the political union in the EU is still a very long way from anything comparable to even a weak federal state, thus outsourcing fiscal responsibilities to technocratic agencies, as suggested by many, is not a realistic option. Therefore EU organs, be that DG EcFin or the often proposed budget tsar, can and should not act as if they were representing a supranational authority, where it is the packaging of intervention which matters, not its size or justification.

As long as different countries exhibit different preferences in terms of public spending and related public provision of services, it is difficult to support the idea of a fiscal union, aimed at improving the cosmetics of public finances in well defined group of countries. The preliminary agreement of June 2012 pointed to this direction, while the compromise in December 2012 has actually prolonged its implementation to undefined later periods of time. Thus the sustaining differences in the pattern of both spending and revenue generation limit the unification of procedures and even more of standardizing major items on the Union level. This holds irrespective of the motives behind unification, also in the future.

\section{On the Drivers of Money Markets: Fundamentals, Appearences and Beliefs}

Analysts of real - as opposed to modeled - money markets have long tried to supersede the world of simple, non-testable axioms. They based their views on actual observations of mass behavior in empirical psychology and adopted behavioral finance approaches. Following Ludwig von Mises they took herd behavior - rather than unlimited rationality - as the basic feature of the workings of money markets. This translates into the focal role of perceptions, beliefs and expectations - phenomena which are testable and observable on the ground, thus are in no need of being assumed or assumed away.

The crisis of 2008-2009 has revived the old question: what is the point of elaborating 'iron laws' that apply to computer displays or paper only? For one, the assumption of efficient markets was that markets do react 'instantenously' and punish ruthlessly each and every trespassing. This logic did work in the minds of the founding fathers of the EMU, who presupposed that it is rational for policy-makers to reform rather than risk the storm of global capital markets. The 
example of Greece and other EMU derailments implicate: this was a conceivable but by no means compelling argumentation. It could have worked, but did not work on the ground. One may wonder for how long some high profile economists may boast of economics not being an experimental science? How long may the pre-occupation with coherence at the expense of relevance and testability survive as the supreme academic maxim?

Thus it would be difficult to over-rate the explanatory power of socio-psychological (soft) factors in the interpretation of financial market outcomes in real world economies. It is well established - at least since the 1920s - that appearances and perceptions matter more than fundamentals in triggering actions - especially mass reactions - on the financial markets. Crashes on the stock exchange invariably follow gossips and panics, rumors and misinformation, sometimes spread on purpose, sometimes just correcting preceding 'safe bets', as was the case with the burst of the dotcom bubble in the early 2000s (but also in old times, such as during the tulip craze). It is also received wisdom that fluctuations following from information asymmetries are inherent features of the market economy, as long as we follow the old distinction between calculable risks and unforeseeable, thus incalculable uncertainty. The latter is a basic feature of money markets, and negating this feature - by attempts to calculate, quantify and thus exclude all potential uncertainty - has surely been one of the fallacies of financial economists over the past four decades. Appreciating this feature would make us rather cautious on the possible applications of the 'macroprudential approach' that recently dominates thinking on global financial regulation.

In short, the substance of the macroprudential approach (Hanson et al. 2011) is the extension of provisions for solid banking behavior including the responsibility structures, to the macroeconomy, and in theory the global economy. The attempt at creating the banking union in the EU, discussed in the preceding section, is a case in point. The underlying idea is the belief that such arrangements may, and indeed will, preempt the recurrence of global financial crises. It would be wrong to deny that appropriate precaution and provisions limiting excessive risktaking in banking may and do contribute to ex post damage control. Still it would be naive to theorize that any regulator could, even in theory, let alone in actual practice, preempt the problem of fundamental uncertainty and resulting lack of foresight at the systemic level. All the less so as informational asymmetries and imperfections tend to accumulate, with informational noise and misperceptions adding to a series of negative synergies, which render actual foresight highly imperfect in any real world situation.

If this insight holds, even in part, in line with the insights of Austrian economics, but also in line with empirical studies on financial crises, than the attempt to overcome the contagion of financial crises in Europe through the centralization of supervision is likely to prove a dead alley. While it is re-assuring to find that the Council of December 2012 rejected the over-ambitious idea to create a single supervision for over 6,000 banks, it is hard not to see that the compromise is based on concessions to the UK rather than theoretical insights. Also the need to accommodate the German taxpayer against his fears of a snowball of bank bailouts, rather than the basic acceptance of limitations on centralized controls which shaped the decision to constrain ECB 
oversight to a mere 100 financial institutions 'of systemic relevance'. By contrast, recent literature (Dürr - Elsig 2012) strongly emphasized the relevance of principal-agent problems and their accumulation in EU policies, even in areas where much less money and power is at stake.

In a political economy approach thus we should not disregard the agency problem, nor the issues of political conflict and lack of professional and personal integrity, issues that usually fall outside the scope of technical econometric analyses of EMU troubles. The role of the latter are quite obvious in the case of successive Greek governments (Visvizi 2012) but we have already indicated the relevance of those items in the Spanish and Irish cases in terms of difficulties, and in the Estonian and Slovak cases as favorable feedbacks, stemming from credible commitment of local governments over a single electoral cycle.

And this leads us to the fundamental question. As long as the EU falls short of being a supranational body, how far its stipulations may go in delivering good performance, when domestic commitment of actors is lacking, on a number of grounds? As detailed analyses (Győrffy 2013) explains, in cases when social and professional consensus translates into high levels of commitment, lacking formal fiscal institutions have not compromised prudent macroeconomic policies, as in Slovakia and Estonia. In the contrarian case existence of formal institutions, sanctions and meticulously elaborated procedures could not forestall degradation not only in Greece, but also in Italy, and as more recent warnings indicate, also in France.

Following the logic of German ordoliberalism, the solution we may offer is the proper sequencing of individual measures. Thus orchestrating professional and social consensus should come first, then policy commitment, followed by institutionalization. Else the cart is put in front of the donkey. For instance, the US has one of the eldest independent fiscal control organs, the Congressional Budget Office, set up in 1974 in reaction to the previous global crisis. Likewise in Germany debt ceilings and corrective rules are anchored in the Constitution. The availability of watchdogs, however, could not prevent the explosion of public debt, reaching $105 \%$ of GDP in the USA and over $90 \%$ in Germany. ${ }^{8}$ By contrast, in Luxembourg and Estonia lacking institutions have not translated into fiscal derailment. Similarly Latvia and Slovakia acted in a resolute manner and attained a quick recovery in the 2010-12 period.

From this line of reasoning it follows that efficiency of economic policies are much more contingent upon societal anchoring and professional consensus than the reference to one or other school of economic ideas. However, this claim is non-reversible: wrong or too abstract - and thus non-applicable - theorems never breed economic success. Reference to lack of effective demand at times when regulatory failures strengthen structural weaknesses is a case in point. Likewise the unwillingness to bear the burden of mistaken decisions by the shareholders is always a policy blunder in a non-socialist economy.

\footnotetext{
${ }^{8}$ Let us note: these rules in Germany are truly biting. In fact, any citizen or a group of them may launch a constitutional appeal to stop the government from misbehaving - as it happened with the Maastricht Treaty or more recently with the European Stability Mechanism. Likewise in Poland exceeding the 60\% debt limit would trigger an automatic correction - thus many observers expect major revisions of Polish debt figures.
} 
As we have seen, the longer the unhealthy twins of lax fiscal and lax monetary policies prevail, the deeper is the suspicion of private markets on the ability and willingness of governments to manage their debts. Therefore the doubt if private and public debts can be managed parallel is also gaining in relevance. And this is not only because of the exceeding of the historical limit of 90\% of debt/GDP ratios (Reinhart - Rogoff 2011). The deteriorating quality of Japanese, French and American debt also exacerbates the problem. The downgrades that reached not only major US banks, but also the EFSF and ESM, as well as France are already warning signs for this.

This only underscores the relevance of psychological factors in both creating and solving the crisis. Without acknowledging the problem there is no remedy - Greece, Italy and Portugal are excellent examples for this insight. On the other hand, chronic fear may also lame action, as the cases of France and Hungary may illustrate. We may only reach, through trial and error, where the optimal level of crisis consciousness emerges, which is a state of mind which mobilizes rather than freezes action.

This insight is reversible. No matter how much fundamentals improve, if this is not appreciated by society at large, the government managing the process is likely to be lost. Improving actual performance is thus a necessary, but by no means a sufficient condition, for sustainable sound economic policies. This is bad news insofar as adjustment measures initiated in Southern Europe and in the large member states have already triggered a series of protest all across Europe. While economics has become non-accessible - owing to its over-emphasis on formalization - the demand for populist suggestions, offering single measure once for all solutions is on the increase. Reviving bad - and mostly failed - theories are unlikely to help, as is the case with the usual practice of ongoing policy improvisation in most of the EU states.

One of the conceivable conclusions of our analysis may go as follows. On the base of empirical observations and of established, testable theories, it is possible to develop an economics which is perhaps less elegant than the mainstream, but is more relevant to solving the crisis of the EU. This applies to both to the level of interpretations and policy recommendations, or more simply, to the descriptive and normative planes. This new approach may be, what the German proverb calls, identical with the long forgotten old one, a systemic approach or ordoliberalism.

\section{References}

Acemoglu, D. - Robinson, S. (2012): Why Nations Fail? New York: Crowne Publishers.

Benczes I. (2011): Nemzeti szintü fiskális szabályok használata az EU-ban (Appliying national level fiscal rules in the EU). Külgazdaság 55(3-4): 55-75.

Connor,G. - O'Kelly, B. (2012): Sliding doors cost-measurement: the net economic cost of lax regulation of the Irish banking sector. World Economy 35(10): 1256-1276.

Csaba,L.(2012(: Perspectives for the euro-zone: consolidation, muddling through or collapse? In.Latoszek,E et al, eds: European Integration in the New Regional and Global Setting. Warsaw: WWZ Press, pp73-90. 
Daianu, D. (2012): The euro-zone crisis and EU governance: tackling a flawed design and inadequate policy arrangements. Acta Oeconomica 62(3): 295-320.

Dürr, A. - Elsig, M. (2012): The European Union's Foreign Economic Policies: A PrincipalAgent Perspective. London and New York: Taylor and Francis.

Dyson, K. - Featherstone, K., eds. (1999): The Road to Maastricht. Oxford: Oxford University Press.

Fama, E. (1970): Efficient capital markets: a review of theory and empirical work. Journal of Finance 25(2): 383-417.

Feldstein, M. (1997): The political economy of European Economic and Monetary Union: political success of an economic liability. Journal of Economic Perspectives 11(4): 23-42.

Feldstein, M. (2008): Resolving the global economic imbalance: the dollar and the US Savings' rate. Journal of Economic Perspectives 22(3): 113-125.

Friedman, M. (1953): The case for flexible exchange rates. In: Friedman, M: Essays in Positive Economics. Chicago: University of Chicago Press.

Garciano, L. (2012): Five lessons from the Spanish caja debalce for a new euro-wide supervisor. http://www.voxeu.org/article/five-lessons-spanish-cajas-debacle-new-euro-widesupervisor, accessed 25 October 2012.

Greenspan, A. (2007): The Age of Turbulance. Adventures in a New World. New York: The Penguin Press.

Győrffy, D. (2013): Institutional Trust and Economic Policy: lessons from the History of the Euro. Budapest and New York: CEU Press.

de Haan, J. - Oosterloo, S. - Schoenmaker, D. (2010): European Financial Markets and Institutions. Cambridge and New York: Cambridge University Press.

Hanson, S. - Kasyhap, A. - Stein, J. (2011): A macroprudential approach to financial regulation. Journal of Economic Perspectives 25(1): 3-28.

Issing, O. - Angeloni, I. - Gaspar, V. (2004): Decision-Making at the European Central Bank. Cambridge and New York: Cambridge University Press.

Laski, K. - Podkaminer, L. (2012): The basic paradigms of EU policy-making need to be changed. Cambridge Journal of Economics 36(1): 253-270.

Lucas, R. E. (1976): Econometric policy evaluation: A critique. In: Brunner, K - Meltzer, A., eds: The Phillips Curve and Labor Markets. New York: Carnegie-Rochester Series on Public Policy, pp. 19-46.

Mayer, T. (2012): Europe's Unfinished Currency: The Political Economics of the Euro. New York: Anthem Press. 
Muraközy, L. (2012): Performance and efficiency of governments in the OECD countries: Experiences of the Great Moderation period. Acta Oeconomica 62(3): 321-344.

Palánkai, T. (2012): Megmenthetö-e az euró övezet? (Can the euro zone be saved?). KözGazdaság 7(1): 15-36.

Reinhart, C. - Rogoff, K. (2011): This Time Is Different. Princeton: Princeton University Press.

van Rie, T. - Mary, I. (2012): The European Union at work? The European Employment Strategy from crisis to crisis. Journal of Common Market Studies 50(2): 335-356.

Sargent, T. (2012): The United States then - Europe Now. Nobel Lecture, available at: www.nobelprize.org, accessed 23 October 2012.

Schnaas, D. (2012): Die Unabhaengigkeit der EZB ist reine Fiktion. Handelsblatt, 10 November

Visvizi, A. (2012): The crisis in Greece and the EU-IMF rescue package: determinants and pitfalls. Acta Oeconomica 62(1): 15-40.

Vörös, I. (2012): Csoportkép Laokoónnal. A magyar Alkotmánybíróság és alkotmánybiráskodás eseta az európai joggal (Laocoön and his sons: the conflictual relationship of the Hungarian Constitutional Court with EU law). Budapest: HVG-Orac and Center for Social Studies of the Hungarian Academy of Sciences. 